\title{
Mapping of the Precambrian basement in the Fiskenæsset region, southern West Greenland
}

\section{Feiko Kalsbeek}

The systematic mapping of the Fiskenæsset region, which began in 1970 (see previous GGU Reports of Activities), was continued in the period June to September. Apart from the author the following geologists took part: J. C. Escher (GGU), W. R. Fitches (Univ. Coll. of Wales, Aberystwyth), C. R. L. Friend (Portsmouth Coll. of Tech.), R. P. Hall (Portsmouth Coll. of Tech.), J. S. Myers (GGU), J. F. G. Sandwall (Chalmers Tekniska Högskola, Göteborg), O. Stecher (Århus University), J. Tomas (Geol. Surv. Prague) and C. B. Zetterstrøm (Randers, Denmark). The two-man field parties were served by two helicopters and the GGU motor cutters $J$. F. Johnstrup and Villiaumit operating from the base camp Midgård. As in earlier years, Ib Olsen (GGU) took care of most of the practical arrangements.

Mapping as far north as Sermilik fjord and Sermilik glacier is now finished; mapping up to $64^{\circ} \mathrm{N}$, the boundary for the Midgård operations, will be concluded in 1975 .

This summer, the general picture of the geology of the area, as established in earlier years (Kalsbeek \& Myers, 1973) has been largely confirmed. It is still not possible to map groups or gneisses of essentially different ages such as the Amitsoq and Nûk gneisses of the Godthaibsfjord region. In the north-easternmost part of the region, mapped by Escher, Stecher and Tomas, well preserved supracrustal rocks are more abundant than farther towards the south, and granitic augen gneisses ('Ilivertalik Granite') which make up a large part of the terrain between Grædefjord and Sermilik become less widespread. At several localities relatively leucocratic, grey amphibolites have been found. Chemical analysis of one of these showed a good andesitic composition. Well preserved pillow lavas, lithologically grading from grey amphibolite to ultramafite, were found by Escher (Escher \& Myers, this report).

Towards the end of the summer, Escher \& Myers (this report) revisited previously mapped areas with the aim of coordinating and synthesizing earlier results for the compilation of the final maps. They were able to show that dioritic and quartz dioritic rocks, as described earlier by Pulvertaft (1972) occur over a larger area than anticipated. Good intrusive relationships were also found for the first time between rocks of the anorthosite complex and the supracrustal amphibolites.

\section{References}

Kalsbeek, F. \& Myers, J. S. 1973: The geology of the Fiskenæsset region. Rapp. Gronlands geol. Unders. 51, 5-18.

Pulvertaft, T. C. R. 1972: Preliminary report on the geology of the area between Kigutilik and Bjørnesund. Unpublished GGU internal report. 